\title{
Genomsekvensering for persontilpasset kreftbehandling
}

\author{
Persontilpasset kreftmedisin basert på svulstens mutasjonsprofil er på vei inn i den kliniske hverdagen. \\ Ny DNA-sekvenseringsteknologi kan brukes til å teste kreftprøver for mutasjoner i ethvert gen av klinisk \\ betydning, og på litt lengre sikt gir dette muligheter for individualisering av behandling vi tidligere knapt \\ har kunnet drømme om.
}

\author{
Rolf I. Skotheim \\ rolf.i.skotheim@rr-research.no \\ Leonardo A. Meza-Zepeda \\ Eivind Hovig \\ Per E. Lønning \\ Ragnhild A. Lothe \\ Ola Myklebost
}

Det er grunn til å tro at kreftbehandlingen vil se helt annerledes ut om få år. Utvikling av en rekke nye legemidler rettet mot spesifikke molekylære signalveier, og påvisning av mutasjoner i disse med genomsekvensering, gir nye muligheter. Men dette er komplisert, siden behandlingseffekten ofte påvirkes av defekter i mange gener og cellulære signalveier.

\section{Molekylærbiologiens rolle i kreftforskningen}

Et av de viktigste resultatene av det humane genomprosjektet var utviklingen av nye DNA-sekvenseringsteknologier (1). De lave sekvenseringskostnadene gir nå helt nye anvendelsesområder. Nå kan vi raskt finne hvilke DNA-endringer som forekommer i den enkelte kreftsvulst. Disse mutasjonene er av flere typer, fra enkeltbaseforandringer til delesjoner, insersjoner eller oppkopiering av større segmenter, eller fusjoner mellom to gener fra forskjellige kromosomområder (2). Utfordringene ligger ikke lenger bare i å identifisere avvikene, men å skille ut dem som driver sykdomsprosessen fra de tilfeldige avvik, eller «støy». Ved å kombinere innsikt i de underliggende molekylære prosesser, ikke bare innenfor en og samme kreftsykdom, men på tvers av sykdommer, oppstår nye muligheter for bedre tilpasset behandling av kreftpasienten. Spesielt viktig er det å ha tilgang til biobanker der man i tillegg til svulstvev har informasjon om hvorledes den enkelte svulst responderte på definerte behandlingsregimer, om svulsten ga metastaser, samt hvorvidt pasienten ble kurert. Ved å sammenholde biologiske funn med kliniske utfall kan vi på denne måten identifisere hvilke fellesnevnere som ga for eksempel resistens mot cytostatika.

\section{Persontilpasset kreftbehandling}

Eksisterende målrettede legemidler

Det første genetiske avviket i kreft ble beskrevet i 1960 og var en kromosomforandring i kronisk myelogen leukemi (KML) (3). Det ble senere vist at dette var resultatet av en translokasjon mellom kromosomene 9 og 22, t(9; 22)(q34; q11) som fusjonerte genene $\mathrm{BCR}$ og $\mathrm{ABL} 1$ (4). Flere tiår senere ble molekylær målrettet terapi introdusert i kreftbehandling. Pasienter med kronisk myelogen leukemi med den spesielle kromosomforandringen, $\mathrm{t}(9 ; 22)$, responderer på imatinib (5), som virker spesifikt mot kinaseaktiviteten til fusjonsproteinet.

Det er siden vist at dette legemidlet også virker på andre typer kreft der denne eller beslektede kinaser er mutert (6), og vi har også flere gode eksempler på mutasjoner som er avgjørende for respons på spesielle typer kreftmedisiner. Lungekreftpasienter med mutert reseptor for epidermal vekstfaktor (EGFR) i kreftcellene responderer på medikamentet gefitinib, og de med det nyoppdagede ALK-fusjonsgenet ser ut til å respondere på ALK-hemmere (7). Melanompasienter med enkeltbasemutasjon i BRAF responderer på medikamentet vemurafenib (8), mens pasienter med tykktarmskreft responderer dårligere på cetuximab hvis svulsten har enkeltbasemutasjon i KRAS (9). Brystkreftpasienter der svulsten har amplifikasjon av protoonkogenet HER2 (ERBB2) har i utgangspunktet en spesielt dårlig prognose (10), men har stor nytte av målrettet behandling mot HER2 (11). Det er stor vekst i antall slike legemidler under utvikling. Den nye sekvenseringsteknologien vil avdekke mange flere muterte gener som alene eller sammen viser seg viktig for behandling av kreftpasienter.

Etter vår oppfatning vil det etter hvert åpne seg betydelige muligheter for persontilpasset behandling innen de fleste kreftformer.

Samme gen kan være mutert i flere tumortyper

Mange målmolekyler for skreddersydd medisin, f.eks. muterte gener og proteiner, har vist seg å forekomme i flere kreftformer enn i den de først ble identifisert (12). Dette har gitt grobunn for en oppfatning om at kreft i større grad bør håndteres ut fra hvilke genetiske endringer som har bidratt til kreftutviklingen og hvilke av disse som er tilgjengelige terapeutiske mål, og ikke i så stor grad som tidligere blir basert på hvilke organer og celletyper kreftcellene har sitt utspring fra.

I kliniske laboratorier analyseres i dag bare få utvalgte kreftrelevante gener, ett og ett, og da bare fra krefttyper der den kreftrelevante genetiske endringen er kjent å være vanlig. Hvert gen som får ny klinisk nytteverdi, vil kreve betydelige ekstraressurser for å etablere godkjente tester, og for hver enkelt kreftpasient der et ekstra gen skal testes. I lys av at flere og flere molekylært målrettede behandlinger blir utviklet, og er aktuelle på tvers av ulike kreftformer, ser vi behov for at vi bør analysere kreftprøver for langt flere genetiske endringer enn dagens praksis. Den nye sekvenseringsteknologien åpner nettopp for full kartlegging av alle mutasjoner i hver svulst, og gjør dermed diagnostikken svært effektiv og totalt sett billigere.

\section{Hver svulst har mange mutasjoner}

De fleste kreftprøver har hundrevis, ofte tusenvis, av genetiske endringer, med unik sammensetning for hver prøve (2). Det er krevende å skille mutasjoner som bidrar til kreftutvikling, og dermed kan ha relevans for behandlingen av den enkelte pasient og svulst, fra de som er tilfeldige genetiske hendelser på grunn av den økte mutasjonsraten i kreftceller. Et annet problem er at mutasjonsbildet endrer seg gjennom kreftutviklingsforløpet, og derfor varierer mellom deler av svulstene (13). Selv muterte proteiner som anses som kreftdrivende kan ha ulike mutasjoner i forskjellige deler av samme svulst (14).

\section{Prinsipper for klinisk utprøving} må revurderes

Dagens regimer for utprøving av legemidler blir uegnet når behandlingen skal tilpasses en enkelt eller noen få pasienter. Svulstens 


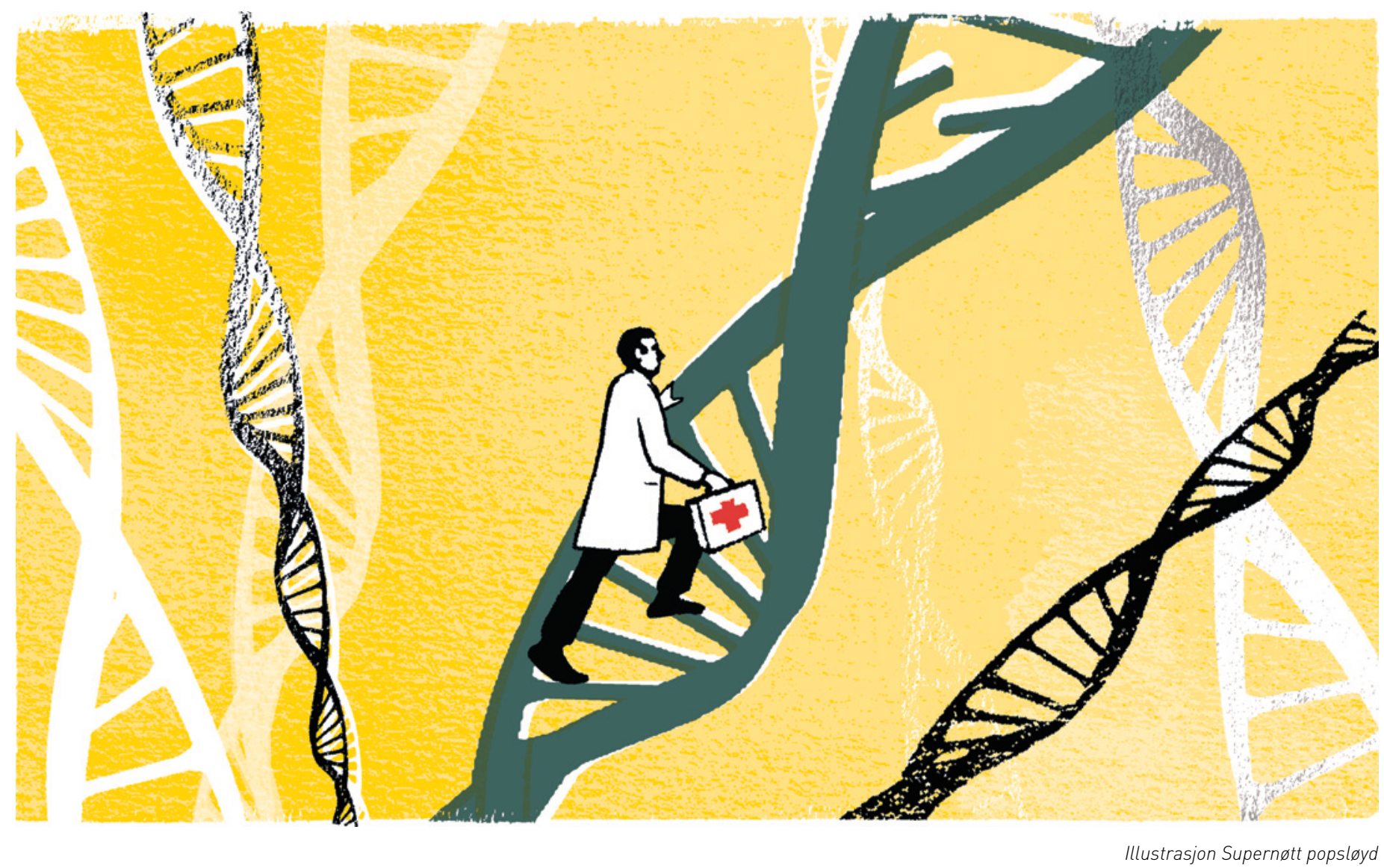

kombinasjon av muterte gener gir mulighet for å kombinere behandling mot flere av disse. Det er vanskelig å foreta relevante kliniske utprøvninger for en slik kombinasjonsbehandling. Vi tror at dette kommer til å sette etablert kreftbehandling, praksis for kliniske utprøvninger og helsevesenet på store prøver.

\section{Tolkingsutfordringen}

Genombasert kreftbehandling vil i stor grad være avhengig av statistikk og informatikk for å håndtere de formidable datamengdene. Analyseresultatene må også kombineres med empirisk oppsamlet molekylær kreftrelevant kunnskap. En rekke prosjekter og firmaer er i gang med å utvikle programvare for tolking av helgenomsekvenser, der det klinisk vesentlige skal skilles fra støy på en automatisert, men kvalitetssikret måte. Med utviklingen av slik programvare for håndtering av store mengder sensitive data, og overføringen av den behandlingsrelevante informasjonen til kliniske IKT-systemer, er datasikkerhet også et viktig, men foreløpig uløst, ledd.
Strategier i internasjonale prosjekter Mange internasjonale institusjoner lanserer i disse dager målrettet sekvensering av gener der mutasjoner indikerer at molekylært målrettet behandling kan oppnås. Først ute med tilbud via et offentlig godkjent laboratorium var Washington University School of Medicine, som utfører målrettet sekvenseringsbasert diagnostikk fra 28 kreftgener. Universitetet i Washington har tidligere utviklet et mindre genpanel, ColoSeq, der sju gener som er forbundet med arvelig tykktarmskreft analyseres (15). Firmaet Foundation Medicine har lansert en bredere test, der 176 kreftrelevante gener blir sekvensert. Analyser av dette genpanelet har allrerede vist at lungekreftassosierte ALK-fusjoner også finnes i tykktarmskreft (16). Ved universitetet i California, San Diego, har de etablert en analyse der 42 kreftgener sekvenseres «ultradypt», dvs. at hver base i disse genene ble sekvensert i gjennomsnitt 24000 ganger, for å finne mutasjoner som er til stede i bare en ytterst liten andel av kreftcellene, men som kan være den del av svulsten som gir resistens og tilbakefall (17).
Ved universitetet i Michigan har de i sin satsing på persontilpasset kreftmedisin satt i gang total helgenom-, eksom- (DNAanalyse der man sekvenserer de $2-3 \%$ av genomet som koder for proteiner) og transkriptomsekvensering (analyse der man kartlegger sekvens til alt RNA i en prøve) (18). De har riktignok erfart at det rett og slett blir for mye informasjon for den enkelte kliniker, og håndterer dette ved at prøvesvarene fra hver enkelt pasient blir diskutert av en multidisiplinær komité med fagfolk fra onkologi, genetikk, patologi, biologi, bioinformatikk og etikk.

\section{Hvilken strategi er best i Norge?}

Vil det for fremtidig genombasert kreftmedisin i Norge være hensiktsmessig å analysere et begrenset genpanel, alle gener («eksomet»), eller hele genomet? For eksempel har Oslo universitetssykehus, Radiumhospitalet, satt i gang en retrospektiv pilotstudie for å sekvensere 612 gener i 100 lungekreftprøver for å identifisere gjengangermutasjoner og mulige nye angrepspunkter for behandling. Prisutvik- 
lingen ved sekvensering gjør det imidlertid stadig mer relevant å sekvensere hele eksomet. Siden det er så mange mutasjoner i et kreftgenom, som ofte også involverer strukturelle endringer og endringer av geners aktivitetsnivå, er det viktig også å kartlegge disse for å legge rasjonelle strategier basert på et større overblikk. Sekvensering av utvalgte genpaneler er heller ikke en gunstig strategi om man ønsker å finne strukturendringer i genomet. I tillegg vil klinisk nytteverdi stadig måtte revideres $i$ lys av ny forskning, som i sin tur raskt vil føre til at slike genpaneler blir utdatert.

\section{Norge, er vi klar?}

Hva er status for genomsekvensbasert kreftmedisin i Norge? Et nystartet initiativ, Norwegian Cancer Genomics Consortium (NCGC) (19), tar sikte på å iverksette genomsekvensering i stor skala av norske kreftpasienter. En fordel vi har i Norge er at pasientene kan følges godt gjennom hele sykdomsforløpet, noe som gir god kvalitet på den kliniske informasjonen. Konsortiumspartnere fra hele landet vil bidra så vi etter hvert kan tilby kreftgenomsekvensering til flest mulig pasientgrupper, og dermed bidra til bedret behandling. Den massive satsingen, som tar sikte på å sekvensere DNA fra tusenvis av kreftpasienter, vil gi verdifull innsikt og forhåpentligvis gi veiledning til gode løsninger.

\section{Rolf I. Skotheim (f. 1975)}

er biolog og forsker i kreftgenomikk. Han er gruppeleder for Genombiologigruppa ved Seksjon for kreftforebygging, Institutt for kreftforskning, Oslo universitetssykehus, -Radiumhospitalet og ved Senter for kreftbiomedisin, Universitetet i Oslo.

Fofatter har fylt ut ICMJE-skjemaet og oppgir ingen interessekonflikter.

\section{Leonardo A. Meza-Zepeda (f. 1970)}

er biokjemiker og forsker i kreftgenomikk. Han er prosjektleder for Mesenkymalgenomikkgruppa ved Seksjon for tumorbiologi, Oslo universitetssykehus, -Radiumhospitalet og leder av Kjernefasilitet for mikromatrise og sekvenseringsteknologi.

Fofatter har fylt ut ICMJE-skjemaet og oppgir ingen interessekonflikter.

\section{Eivind Hovig (f. 1953)}

er biolog og forsker i kreftgenomikk og bioinformatikk, og er gruppeleder innen disse feltene ved Seksjon for tumorbiologi, Oslo universitetssykehus, -Radiumhospitalet og leder kjernefasiliteter for genotyping og bioinformatikk. Fofatter har fylt ut ICMJE-skjemaet og oppgir følgende interessekonflikter: Han har aksjer i PubGene og har mottatt honorar fra Geneseque.

\section{Per Eystein Lønning (f. 1953)}

er lege, spesialist i terapeutisk onkologi. Han er faglig ansvarlig for brystkreftbehandlingen ved Kreftavdelingen, Haukeland universitetssykehus, professor ved Universitetet i Bergen, og leder translasjonell forskningsgruppe på brystkreft i Mohn Kreftforskningslaboratorium. Fofatter har fylt ut ICMJE-skjemaet og oppgir ingen interessekonflikter.

\section{Ragnhild A. Lothe (f. 1958)}

er professor i kreftbiologi og leder av Seksjon for kreftforebygging, Institutt for kreftforskning, Oslo universitetssykehus, Radiumhospitalet og nestleder av Senter for fremragende forskning-kreftbiomedisin, Universitetet i Oslo. Fofatter har fylt ut ICMJE-skjemaet og oppgir ingen interessekonflikter.

\section{Ola Myklebost (f. 1955)}

er cellebiolog og professor i kreftbiologi og bioinformatikk. Han leder Gruppe for mesenkymal kreftbiologi ved Seksjon for tumorbiologi, Oslo universitetssykehus, Radiumhospitalet, er nestleder i CAST - Kreftstamcellesenteret, et senter for forskningsdrevet innovasjon, og leder Nasjonalt kreftgenomikkonsortium. Fofatter har fylt ut ICMJE-skjemaet og oppgir ingen interessekonflikter.

\section{Litteratur}

1. Lander ES, Linton LM, Birren B et al. Initial sequencing and analysis of the human genome. Nature 2001; 409: 860-921.

2. Stratton MR, Campbell PJ, Futreal PA. The cancer genome. Nature 2009: 458: 719-24.

3. Nowell PC, Hungerford DA. Chromosome studies on normal and leukemic human leukocytes. J Nat Cancer Inst 1960; 25: 85-109.

4. Rowley JD. Letter: A new consistent chromosomal abnormality in chronic myelogenous leukaemia identified by quinacrine fluorescence and Giemsa staining. Nature 1973; 243: 290-3.

5. Druker BJ, Tamura S, Buchdunger E et al. Effects of a selective inhibitor of the Abl tyrosine kinase on the growth of Bcr-Abl positive cells. Nat Med 1996; 2: $561-6$.
6. Buchdunger E, Cioffi CL, Law $\mathrm{N}$ et al. Abl proteintyrosine kinase inhibitor STI571 inhibits in vitro signal transduction mediated by c-kit and plateletderived growth factor receptors. J Pharmacol Exp Ther 2000: 295: 139-45.

7. Soda M, Choi YL, Enomoto $M$ et al. Identification of the transforming EML4-ALK fusion gene in nonsmall-cell lung cancer. Nature 2007; 448: 561-6.

8. Flaherty KT. Puzanov I, Kim KB et al. Inhibition of mutated, activated BRAF in metastatic melanoma. N Engl J Med 2010; 363: 809-19.

9. Karapetis CS, Khambata-Ford S, Jonker DJ et al. $\mathrm{K}$-ras mutations and benefit from cetuximab in advanced colorectal cancer. N Engl J Med 2008 359: 1757-65

10. Slamon DJ, Clark GM, Wong SG et al. Human breast cancer: correlation of relapse and survival with amplification of the HER-2/neu oncogene. Science 1987: 235: 177-82.

11. Romond EH, Perez EA, Bryant J et al. Trastuzumab plus adjuvant chemotherapy for operable HER2-positive breast cancer. N Engl J Med 2005; 353: 1673-84

12. Thomas RK, Baker AC, Debiasi RM et al. Highthroughput oncogene mutation profiling in human cancer. Nat Genet 2007; 39: 347-51.

13. Gerlinger M, Rowan AJ, Horswell S et al. Intratumor heterogeneity and branched evolution revealed by multiregion sequencing. $N$ Engl $J$ Med 2012; 366: 883-92

14. Snuderl M, Fazlollahi L, Le LP et al. Mosaic amplification of multiple receptor tyrosine kinase genes in glioblastoma. Cancer Cell 2011: 20: 810-7.

15. Pritchard CC, Smith C, Salipante SJ et al. ColoSeq provides comprehensive lynch and polyposis syndrome mutational analysis using massively parallel sequencing. J Mol Diagn 2012; 14: 357-66.

16. Lipson D, Capelletti M, Yelensky R et al. Identification of new ALK and RET gene fusions from colorectal and lung cancer biopsies. Nat Med 2012; 18 $382-4$

17. Harismendy O, Schwab RB, Bao L et al. Detection of low prevalence somatic mutations in solid tumors with ultra-deep targeted sequencing. Genome Biol 2011; 12: R124

18. Roychowdhury S, lyer MK, Robinson DR et al. Personalized oncology through integrative highthroughput sequencing: a pilot study. Sci Trans Med 2011; 3: 111ra121.

19. Norwegian Cancer Genomics Consortium (NCGC) www.cancergenomics.no (3.9.2012).

Mottatt 29.6. 2012, første revisjon innsendt 30.8. 2012, godkjent 13.9. 2012. Medisinsk redaktør Kristin Viste. 